\title{
"Znać iżeście i bestyj podlejszy” Zoomorficzne inkarnacje Szatana w Żywotach świętych Piotra Skargi
}

\section{Abstract \\ "You Are Evidently Inferior Even to Beasts." Zoomorphic Incarnations of Satan in Piotr Skarga's The Lives of the Saints}

The paper presents the animal incarnations of Satan in the The Lives of the Saints (Żywoty świętych) by Piotr Skarga. Animal motifs are not independent elements in this work, but only part of larger narrative entireties, so-called miracula, which have not yet been analysed. Scholars (H. Barycz, J. Tazbir) considered them elements that depreciated a monumental work of art. These views have been revised recently. Newer findings (by authors such as A. Kapuścińska, A. Ceccherelli, A. NowickaJeżowa, K. Kiszkowiak) shed a slightly different light on the miraculous plots in The Lives of the Saints. However, even these researchers do not offer detailed analyses of miracula. On the contrary, they publish panoramic, comprehensive studies that usually present such texts in the context of a specific problem (e.g. the influence on the shape of post-Tridentine devotion). In this paper, Cybulska attempts to interpret animal motifs using the findings of the so-called Silesian school of micrology. This method seems appropriate as it involves focusing on detail. Moreover, as Aleksander Nawarecki stated, "The aspect of degradation, or rejection is important." This is how miracula were perceived for a long time-as elements that diminish the value of The Lives of the Saints. Are miracular motifs, and specifically animal motifs present in them, irrelevant from the perspective of literary studies? This paper is intended to 
demonstrate that this is not the case. Although scattered in a large text and seemingly of little value to its interpretation, these motifs are in fact carriers of important content. They show how the nature and ontology of evil were understood and how the influence of evil on man was perceived in the epoch in which Lives were written.

Keywords: Piotr Skarga, Żywoty świętych, Lives of Saints, miracula, evil, Satan

Pamięci Profesora Franciszka Pepłowskiego, wielkiego miłośnika „bestyj” wszelakich: zarówno fantastycznych (literackich), jak i prawdziwych, świat Boży napetniajacych.

[...] etymologia tytułowego terminu [tj. słowa „miniatura” - E.C.-B.] wbrew pozorom nie wywodzi się od łacińskiego przymiotnika minimus (mały), lecz od „minii” (tlenek ołowiu), czerwonego barwnika, którym średniowieczni miniatorzy wypisywali najważniejsze partie tekstu, teologiczne pojęcia, ważne myśli i symbole. Gotycka miniatura, nie oznaczała dziełka o skromnych rozmiarach, lecz - istotność, a nawet wyjątkowość samego komunikatu ${ }^{1}$.

Niniejsza praca metodologicznie nawiązuje do szkoły śląskiej mikrologii. Podstawowym postulatem mikrologów było zwrócenie się ku tym częściom badanego dzieła, które są uznawane za nieważne, a nawet obniżające jego wartość. Jak konstatuje Aleksander Nawarecki: „Ważny jest aspekt degradacji, odrzucenia, a nawet wstrętu (status fragmentów, ułamków, okruchów, resztek, odpadów, odchodów, ochłapów itp.)”2. Otóż reprezentacje zwierząt w Żywotach świętych

1 A. Nawarecki, wstęp do: Miniatura i mikrologia literacka, t. 2, red. A. Nawarecki, Katowice 2000, s. 8.

2 Zob. A. Nawarecki, O śląskiej szkole mikrologii (1999-2005). Garść wspomnień, „Forum Poetyki” 2017, s. 13, http://fp.amu.edu.pl/o-slaskiej-szkole-mikrologii-1999-2005-garsc-wspomnien/ (dostęp: 19.09.2019); zob. też tomy zbiorowe: Miniatura i mikrologia literacka, t. 1-3, red. A. Nawarecki, Katowice 2000-2003, oraz Skala mikro w badaniach literackich, red. A. Nawarecki, M. Bogdanowska, Katowice 2005. 
Piotra Skargi niewątpliwie mają taki właśnie status: nie są czymś najistotniejszym. Znani badacze, wśród których należy wymienić Janusza Tazbira, Henryka Barycza, księdza Henryka Frosa, Jakuba Lichańskiego, jak również uczonych młodszego pokolenia: Andreę Ceccherellego, Annę Kapuścińską, Magdalenę Komorowską czy Krzysztofa Koehlera, w swych pracach poświęconych Skardze nie zajmowali się takimi, by tak rzec, drobiazgami. Bardziej interesowali się walorami retorycznymi dzieła jezuity, rekonstruowaniem wzorców osobowych czy modelu pobożności, wyrosłej już na gruncie reformy potrydenckiej, problemami edytorskimi etc. Bibliografia skargowska, obejmująca opracowania, które powstały jako rezultat namysłu nad wyżej wymienionymi aspektami Żywotów, jest niezwykle bogata. Uczeni nie skupiali się na szczegółowej analizie wątków mirakularnych ani tym bardziej motywów zwierzęcych, które w opowieściach o cudach się pojawiają. Trzeba powiedzieć nawet więcej: przez całe dziesięciolecia zawarte w Żywotach miracula uznawano za fragmenty poślednie, umniejszające wartość dzieła kaznodziei. Przez prace Barycza, a potem Tazbira upowszechniło się stwierdzenie, że stanowią one relikty myślenia średniowiecznego i winny być oceniane negatywnie: jako przejaw kwietyzmu, naiwnej pobożności, w której przeważał element emocjonalny nad racjonalnym. Nieco inne światło rzuciły na te wątki refleksje Anny Kapuścińskiej, która w książce „Żywoty świętych" Piotra Skargi. Hagiografia - parenetyka - duchowość ${ }^{3}$ polemizuje z utartymi sądami o Żywotach i udowadnia, że model pobożności kreowany przez Skargę oraz jego podejście do czynionych przez świętych cudów są inne niż w średniowieczu, nowoczesne, wyrastające już z reformy trydenckiej. Wiązało się to $\mathrm{z}$ aspiracjami do tego, by hagiografię uczynić częścią historiografiił. Także obszerne studium Aliny Nowickiej-Jeżowej Pokolenia trydenckie między tradycja

${ }^{3}$ A. Kapuścińska, „Żywoty świętych” Piotra Skargi. Hagiografia - parenetyka duchowość, Szczecin 2008.

${ }^{4}$ A. Ceccherelli, Od Suriusa do Skargi. Studium porównawcze o „Żywotach świętych", przeł. M. Niewójt, Izabelin 2003, s. 43 i nn. 
a wyzwaniami przyszłości $i^{5}$, w którym skrupulatnie bada ona źródła potrydenckiego modelu polskiej pobożności, jest ważnym głosem przeciwko uproszczeniom, które pojawiały się w związku z analizą dzieła jezuity. Trzeba jednak zaznaczyć, że nawet i te prace, choć wnoszą istotne i nowe informacje na temat Żywotów, bardziej dotyczą całościowo opisywanych zagadnień, na przykład wspomnianego wzoru pobożności czy stosunku wiernych do wątków mirakularnych w dobie potrydenckiej, niż detali takich jak motywy zwierzęce. Drobiazgowe ich przeanalizowanie pozostaje kwestią wciąż otwartą. Jakiś czas temu pojawiła się wprawdzie monografia Katarzyny Kiszkowiak ${ }^{6}$, która opisuje cuda w Żywotach. I choć badaczka wykonała dużą pracę, gdyż skatalogowała większość pojawiających się w dziele kaznodziei niezwykłych zjawisk i zestawiła je z odpowiednimi fragmentami Złotej legendy, to, ze względu na objętość ukazanego materiału, niewiele miejsca poświęciła interpretacji miraculów. Monografia ta może być przydatna dla kolejnych badaczy, którzy zechcą przeanalizować te zagadnienia bardziej szczegółowo.

Obrazy zwierząt u Skargi są najczęściej ambiwalentne. To, że jakieś zwierzę w jednym żywocie jest ucieleśnieniem zła, nie oznacza, że taką samą rolę odegra w kolejnej opowieści (na przykład w żywocie św. Antoniego lew to uosobienie diabła, ale w historiach o męczennikach czy pustelnikach jest stróżem dziewiczej czystości, sługą i obrońcą wybrańców Bożych). I to stanowi o oryginalności dzieła jezuity ${ }^{7}$, który unika powielania wzorów, nie sięga po spetryfikowane symbole, a przynajmniej nie jest to regułą. Przedmiotem tej pracy jest jednak przedstawienie jedynie demonicznych reprezentacji zwierząt i na tym

${ }^{5}$ A. Nowicka-Jeżowa, Pokolenia trydenckie między tradycja a wyzwaniami przyszłości, w: Formowanie kultury katolickiej w dobie potrydenckiej. Powszechność i narodowość polskiego katolicyzmu, red. J. Dąbkowska-Kujko, (Kultura Pierwszej Rzeczypospolitej w Dialogu z Europą. Hermeneutyka Wartości, t. 6), Warszawa, 2016, s. 48-57.

${ }^{6}$ K. Kiszkowiak, W kręgu topiki hagiograficznej. „Żywoty świętych” Piotra Skargi, Kraków 2008.

7 Zob. na przykład opisywany poniżej wątek „gołębicy sprosnej”. 
poprzestanę, bowiem wydają się one bardziej złożone niż przypadki, w których stworzenia te ukazywane są w sposób dosłowny. Portrety zwierząt, wzmianki o nich są w obrębie Żywotów rozproszone i trudno je jakoś uporządkować czy sklasyfikować; wydaje się, że sprawdziłby się tutaj najprostszy podział, to jest wyodrębnienie tych partii tekstu, w których jest mowa o zwierzętach rozumianych dosłownie, oraz tych, w których są one ukazywane w sposób symboliczny. Ten podział nie zawsze jednak się sprawdza, bowiem czasem granice między jednym a drugim sposobem prezentowania tych stworzeń nie są oczywiste i ostre. Po co zwierzęce motywy w ogóle badać, skoro, jak się wydaje, nie mają one jakiegoś ważnego znaczenia? Co daje badaczowi zajmowanie się rozproszonymi, rzec by można marginalnymi, wątkami w obrębie monumentalnego, dwutomowego dzieła? Otóż: te właśnie cząstki Skargowego operis to jest wciąż terra incognita. Owe niepozorne „odpryski” są nośnikami interesujących treści, przede wszystkim związanych z filozofią jezuity, jego oglądem świata, ale też stanowią część ogromnego rezerwuaru znaków ówczesnej kultury. Z nich wyłania się stosunek kaznodziei do otaczającego go uniwersum, które nie tylko w tym utworze, ale i w innych jego dziełach jawi się wciąż jako adekwatne do doskonałego, scholastycznego modelu hierarchicznej drabiny bytów, w której poszczególne stworzenia zajmują swoje „przyrodzone”, czy też „naturalne”, miejsce. Wreszcie: analiza takich właśnie detali przynosi wiele ciekawych (i trudnych do odkrycia w inny sposób) informacji na temat Skargowskiej ontologii zła i dobra, ich formy (mam na myśli także formy jak najbardziej fizyczne, namacalne) oraz natury (Arystoteles powiedziałby: „istoty”).

Jako wysłannicy sił demonicznych animalia bywają portretowane za pomocą różnorakich środków, nierzadko bardziej skomplikowanych niż w przypadkach, gdy jezuita mówi po prostu o zwierzętach jako takich. W artykule zajmę się omówieniem figur zwierzęcych niejako od razu kojarzonych z siłami nieczystymi (jak np. wąż, smok, kot), ale przedstawię także stworzenia, których obecność w diabelskim zwierzyńcu może nieco dziwić (np. gołębica - zwykle utożsamiana z obecnością Ducha Świętego, pies - zazwyczaj łączony z wiernością, czy lew - będący emblematem odwagi, a nawet prefiguracją Chrystusa). 
Wśród wielu fragmentów, w których byty demoniczne zjawiają się pod postacią zwierząt, jest niezwykle efektowna scena, którą można uznać za jedną z fundamentalnych w Żywotach, mianowicie kuszenie św. Antoniego. Chociaż Skarga napisał ten żywot u schyłku XVI wieku (pierwsze, wileńskie, wydanie Żywotów pochodzi z 1579 r.), to oddziałuje on na wyobraźnię także współczesnego czytelnika. Jest w tej scenie coś przejmującego. Nieprzypadkowo historia tego właśnie świętego, a konkretnie jego zmagania z diabłem, inspirowała takich malarzy, jak choćby Martin Schongauer, który portretował też inne święte postacie (np. św. Marcina czy Michała Archanioła, a także apokaliptyczną niewiastę, walczących ze smokiem), czy Hieronim Bosch. Ten drugi był zafascynowany postacią świętego i sportretował go kilkakrotnie. Najważniejszymi przedstawieniami, które wyszły spod jego pędzla, są Kuszenie św. Antoniego (obecnie w muzeum Prado w Hiszpanii) oraz tryptyk pod tym samym tytułem, przechowywany w muzeum Arte Antiga w Lizbonie ${ }^{8}$. Oba dzieła Boscha wypełniają dziwne stwory, które już wedle pierwotnej, średniowiecznej wersji legendy o św. Antonim autorstwa Jakuba de Voragine miały się pojawić przed świętym w celu przestraszenia go i doprowadzenia do szaleństwa, aby eremita odwrócił się od Boga i nie uzyskał doskonałości, do której aspirował. Można więc uznać oba te przedstawienia za obraz psychomachii, ale i - być może - walki z własną wyobraźnią. Takiego zdania był Ryszard Przybylski, który w książce Pustelnicy $i$ demony dokonał analizy tej właśnie sceny i zinterpretował ją jako obraz boju z własnymi urojeniami, spowodowanymi wyniszczającą ascezą ${ }^{9}$ Inaczej przedstawia to Skarga, ale nie zapominajmy, że jego wersja jest wersją hagiograficzną, a więc ma za zadanie przedstawić pewne fakty z życia świętego, a nie zajmuje się ich interpretacją (część interpretacyjna każdego z żywotów to

8 Miałam przyjemność oglądać ten obraz kilkakrotnie podczas pobytów naukowych w Lizbonie. Za każdym razem oddziałuje on na kontemplatora inaczej, ale zawsze porusza. Poznać zaś tego dzieła chyba nie sposób, a to ze względu na mnogość zgromadzonych na nim fantasmagorycznych bestii.

9 R. Przybylski, Pustelnicy i demony, Kraków 1994, s. 57 i nn. 
bowiem nie on sam, ale tzw. obrok duchowny, będący komentarzem do danego żywota $)^{10}$. W tym konkretnym przypadku jezuita opisuje fizyczny, nie tylko mentalny, kontakt Antoniego z bytami demonicznymi. Święty, wedle źródeł patrystycznych, miał przeżyć trzy próby i tak też relacjonuje to Skarga. Za pierwszym i drugim razem Szatan starał się go odwieść od ascezy za pomocą łagodnej namowy (było to więc coś, co teologia określa mianem „kuszenia szatańskiego”) ${ }^{11}$. Demon przypomniał mu przepych rodzinnego domu, bogactwa, których Antoni był dziedzicem. Kolejny atak również nie miał jeszcze charakteru otwartej walki: diabeł próbował skusić świętego, odwołując się do jego cielesności. Dopiero trzecie uderzenie przybiera formę bezpośredniego, fizycznego kontaktu (teolog egzorcysta powiedziałby: „opresji demonicznej”). Szatan zjawia się przed świętym po to, by dokonać jego unicestwienia:

Czart [...], widząc się być od młodzieńca podeptanym, z wielkim wojskiem widomie na jego chałupkę uderzył i tak go srodze zbił na ciele, iż za martwego kilka dni leżał. [...] I uczynił czart nań ostatni najazd: zebrawszy się z towarzystwem i z wojskiem w osobie rozmaitych bestyj, lwów, niedźwiedziów, wilków, wieprzów, psów i byków i innych srogich zwierzów, na onę jego chałupkę uderzył, którą rozproszywszy, straszyć go ryki onych sprosnych bestyj i przymierzanim rozmaitych śmierci począł. A on, acz prze onę boleść cielesną zbity, ciężko stękał i podnieść się nie mógł - wszakże sercem wielkim nieustraszony na ono wojsko wołał: Znać, iż mocy i siły nie macie! Wszak jeden z was mógłby mię, jako jednego robaczka, pożrzeć [tj. pożreć - E.C.-B.]: jeszcze na mię twarzy niemych i nierozumnych używacie: znać, iżeście i bestyj podlejszy. Jeśli od Boga mego moc na mię dana wam jest: otom jest. Zgubcie, zatraćcie, czyńcie to, co wam kazano, ja wam nie ustąpię. A wiem, iż mi nic uczynić bez wolej Pana mego nie możecie. Próżno się kusicie - znak krzyża ś<wietego> a wiara w Pana naszego Jezusa

10 O obrokach zob. A. Kapuścińska, „Żywoty świętych” Piotra Skargi..., s. 69 i nn. (rozdział III).

11 Odwołuję się do współczesnej terminologii egzorcysty Gabriela Amortha, zob. G. Amorth, Wyznania egzorcysty, przeł. W. Zasiura, Częstochowa 2006. Autor wyróżnia aż pięć stopni działania szatańskiego: 1) kuszenie, 2) opresje demoniczne (nękanie), 3) posiadanie diabelskie, 4) nawiedzenie diabelskie, 5) opętanie. 
Chrystusa, mocnym mi a niedobytym przeciw wam murem jest. Zatym, jako ćma od słońca i proch od wiatru, nieprzyjaciele się rozproszyli i uciekli, a światłość go wielka $\mathrm{z}$ nieba nawiedziła, i chałupka jego w cale stanęła ${ }^{12}$.

W scenie tej czart naciera nie pojedynczo, ale jako armia złych duchów. Przybierają one postaci zwierząt, które są przerażające ze względu na swe atrybuty. Atrybutami owymi są nie tylko drapieżność (wilki, lwy, psy), ale i siła (byki, niedźwiedzie) czy odrażający wygląd (wieprze) bądź kontaminacja tych cech (np. niedźwiedź jest i drapieżny, i silny). Zwraca uwagę dysproporcja po obu stronach tego frontu: wojsko fantasmagorycznych kreatur kontra pojedynczy człowiek. Nie uchodzi to oczywiście uwadze świętego, który, choć ma świadomość swej kondycji bycia „robaczkiem” wobec zastępu demonów, uparcie trwa pogrążony w modlitwie. Ów upór został w tekście wyrażony wprost. Antoni mówi: „ja wam nie ustą pię”, gdyż wyznawana przezeń wiara w Chrystusa „mocnym mi a nied obyt y m przeciw wam murem jest”. Z drugiej strony - co wydaje się chyba najbardziej zaskakujące i właśnie to inspirowało pisarzy i malarzy - święty nie stawia oporu, nie odpowiada atakiem, pozostaje fizycznie bierny. Bardzo dobrze widać to na wspomnianych wyżej obrazach Schongauera i Boscha, zwłaszcza zaś tego pierwszego. Wydaje się, że zaiste tłum dzikich bestii rozszarpie świętego na strzępy. Tak się jednak nie dzieje, gdyż Antoni ma nad nimi przewagę, którą zdobywa w trakcie tego straszliwego starcia dzięki medytacji. Odsłania ona przed nim samą istotę bytów demonicznych, mianowicie ich ontologiczną pustkę. Czymże bowiem w rzeczywistości są owe dręczące świętego bestie? Niczym. Nie mają nawet własnego kształtu, formy, a zatem zagrożenie, które zdają się stwarzać, jest pozorne. Straszliwa postać, jaką przybierają, nie przynależy do nich, ale jest jedynie maską „pożyczoną” od

12 P. Skarga, Żywoty świętych, Wilno: Drukarnia Radziwiłłowska, 1579, s. 56. Wszystkie cytaty pochodzą z tego wydania, dalej oznaczam je skrótem SkarŻyw z oznaczeniem numeru strony. Uwspółcześniłam pisownię i interpunkcję. Wyróżniłam też pewne fragmenty (lub słowa), na które chciałabym zwrócić uwagę czytelnika. 
„niemych twarzy”, czyli zwierząt ${ }^{13}$. Antoni, obnażywszy nicość szatańskiego wojska, jego pustkę, stwierdza, że jest to byt ontologicznie najmniej doskonały, gorszy nawet od zwierząt („znać, iżeście i bestyj podlejszy"). W tekst ten zostają więc wpisane bardzo istotne informacje o charakterze teologicznym, filozoficznym czy też - demonologicznym, gdyż w przytoczonej scenie jak w soczewce skupiają się ówczesne poglądy na temat natury zła (Augustyńskie pytanie unde malum?, ale i przeświadczenie, iż diabeł jest zaprzeczeniem bytu, zaś zło jest tylko pewnym zjawiskiem dopuszczonym przez Boga w stworzonym przezeń świecie; takie stanowisko było też zgodne z nauką Plotyna czy Ojców Kapadockich) ${ }^{14}$. Dowiadujemy się czegoś o naturze zła, które, choć przygodne, to jednak może być niebezpieczne. Otóż zwykle zjawia się ono nie w swej właściwej postaci (co jest logiczne: wszak jej nie ma), ale posługuje się maską, przebraniem, manifestuje się za pośrednictwem stworzenia. Jest to możliwe, gdyż w świetle nauki o grzechu pierworodnym natura uległa skażeniu złem. Widać to już w scenie biblijnej, kiedy Szatan zbliża się do pierwszych rodziców pod postacią zwierzęcia: węża, odtąd tradycyjnie utożsamianego z diabłem. A zatem Szatan, który w wyniku upadku stał się nie-by tem, wykorzystuje inne stworzenia, aby zaszkodzić by tow $\mathrm{i}$, zwłaszcza zaś tym, którzy poszukują Boga ${ }^{15}$.

W żywocie św. Antoniego mamy do czynienia z dwoma, spośród pięciu, sposobami oddziaływania diabła na człowieka: kuszeniem i dręczeniem (opresją szatańską). Znajdziemy na kartach Żywotów jeszcze i opętanie - najcięższy z przypadków związany z ingerencją sił nieczystych. Szatan pod postacią zwierząt najczęściej jednak manifestuje swą obecność za pośrednictwem pierwszych dwóch sposobów,

${ }^{13}$ Scenę tę analizowałam już wcześniej, w artykule "Żywoty świętych" Piotra Skargi - biografie transgresyjne. Prolegomena do przyszlych badań, „Autobiografia. Literatura. Kultura. Media” (2018), nr 2, s. 13-36.

${ }^{14} \mathrm{H}$. Cholwińska, Zagadnienie genezy zła w myśli św. Augustyna, „Studia Theologica Varsaviensia" 37 (1999), nr 1, s. 87-113; zob. też: J. Nizwandowski, Bóg a zło. Na marginesie „O naturze dobra”, „Znak” 95 (1962), s. 675.

${ }^{15}$ H. Cholwińska, Zagadnienie genezy zła..., s. 90. 
co wydaje się dość oczywiste, bowiem aby wejść w ciało człowieka i zawładnąć nim, nie potrzebuje on używać żadnej maski, a nawet nie jest ona wskazana, gdyż wówczas mógłby być zauważony. Kuszenia i/lub dręczenia diabelskie, kiedy to Szatan zjawia się pod postacią bestii, pojawiają się przeto w dziele jezuity nieco częściej. Wśród historii, w których występują przywołane epizody pokusy lub nękania, uwagę przyciąga żywot św. Dominika, gdyż opisuje przypadek odmienny: nawiedzenia szatańskiego. Co może wydać się nieprawdopodobne, ma ono miejsce w kościele:

Po jednym jego kazaniu przyszły do kościoła dziewięć szlachetnych pań w kacerstwie uwichłanych, radząc się, co czynić miały [...] a owo wyszedł do nich kot sprosny i wielki jak pies, straszliwy, z krwawym językiem i długo się między nimi trąc, wielce zastraszył. I potym po powrózku, który u dzwonka był, wzgórę się puściwszy - wzniknął [SkarŻyw 722].

W tym wypadku Szatan przybiera postać demonicznego kota, który jednak jest „wielki jak pies”, co pozwala go uznać za swego rodzaju hybrydę, to jest istotę mieszaną, bodącą połączeniem dwóch lub większej liczby stworzeń. Obecność kota w diabelskich szeregach nie dziwi: od czasów średniowiecza zwierzęta te były kojarzone z ciemnymi mocami i pozostawały towarzyszami czarownic (czego późnym i chyba najbardziej znanym świadectwem jest Behemot z Mistrza i Małgorzaty Bułhakowa ${ }^{16}$ ). Do ukształtowania się takiego obrazu tego zwierzęcia w największym stopniu przyczyniła się jego powierzchowność (futro sypiące iskry, jarzące się w ciemności oczy) oraz obyczaje (koty były uznawane za rozwiązłe, gdyż podczas zalotów i parzenia się wydają głośne, niepokojące odgłosy) ${ }^{17}$. Z drugiej

16 Behemot, który „nie wiadomo skąd się wziął”, też jest hybrydą: wielki (czy też „spasiony”) jak wieprz, ma „wąsy kawalerzysty”, jest czarny „jak sadza lub gawron” (M. Bułhakow, Mistrz i Małgorzata, przeł. L.A. Przebina, G. Przebina, I. Przebina, Kraków 2016, s. 58).

17 P. Rutkowski, Kot czarownicy. Demon osobisty w Anglii wczesnonowożytnej, Kraków 2012; O. Kielak, Zwierzęta domowe a postaci demoniczne w języku i kulturze, „Kultura i Historia” (2017), nr 32, s. 133; D. Sztych, Kot-dobrotliwe bóstwo, czy po- 
jednak strony trzeba pamiętać, że stworzenie to było uznawane za filozofa. Lexicon Jana Mączyńskiego z 1564 roku, a więc chronologicznie całkiem bliskie Żywotom, podaje, że łacińskie słowo cattus w użyciu przymiotnikowym oznacza tyle co „chytry, mądry”"18. I rzeczywiście: zwierzę to postrzegano w sposób ambiwalentny: $z$ jednej strony przypisywano mu konszachty z diabłem, $\mathrm{z}$ drugiej - chwalono za spryt, a nawet widziano w nim mędrca, od którego mnisi mogą się uczyć trudnej sztuki medytacji oraz cierpliwości i pracowitości (przykładem takiego potraktowania kota jest staroirlandzki wiersz z IX wieku zatytułowany Mnich $i$ jego kot $^{19}$ ). Mnisi często trzymali koty w klasztorach, żeby uchronić się przed plagami myszy, i zdołali dobrze poznać ich zwyczaje ${ }^{20}$. Cenili je za „chędogość”, czyli zamiłowanie do czystości. O kocich przymiotach piszą stare polskie zielniki, na przykład Stefana Falimirza O ziołach i o mocy ich, w którym autor przedstawił całkiem obszerną charakterystykę tego zwierzęcia. Zawiera ona przymioty, za które cattus był ceniony przez braci zakonnych:

Kot $\mathrm{z}$ łacińskiego jakoby roztropny a opatrzny. Jest zwierzę myszam nieprzyjazne. Jest też sromieźliwe, a miłuje chędogość. Barwa jemu przyrodzona jest szara, lodowi podobna, insze barwy przypadłe od strawy, które jedzą, zwłaszcza domowi ${ }^{21}$.

miot szatana?, „Przegląd Hodowlany” (2011), nr 11, s. 24-27; J.C. Cooper, Zwierzęta symboliczne i mityczne, przeł. A. Kozłowska-Ryś, L. Ryś, Poznań 1998.

${ }_{18} \mathrm{~J}$. Mączyńki, Lexicon latino-polonicum ex optimis latinae linguae scriptoribus concinnatum, Królewiec: Jan Daubman, 1564, s. 41c.

19 Ten, oraz inne godne uwagi wiersze, znajdują się w zbiorze: Eire. Wiersze irlandzkie: VI-XIX wiek, wybór, przeł. i oprac. E. Bryll, M. Goraj-Bryll, [zebrał i oprac. R. Bąk], Warszawa 2004.

${ }^{20}$ Koty w klasztorach żyją do dziś. Zostało to ukazane na przykład w filmie Wielka cisza o życiu współczesnych kartuzów. Bracia opiekują się mieszkającymi w klasztorze kotami, a nawet dopatrują się w kociej społeczności hierarchii podobnej do zakonnej (jeden z kocurów zostaje określony jako „przełożony” pozostałych). Jako ciekawostkę należy dodać, że istnieje rasa kota związana z tym zakonem: kot z Chartreux, kot kartuzki lub (po prostu) kartuz. Koty hoduje się też w klasztorach buddyjskich, gdzie są uczone sztuczek (np. przeskakiwania przez obręcz). Tresura kotów jest trudna i uznawana za jedną z metod pracy duchowej.

${ }^{21}$ S. Falimirz, O ziołach i o mocy ich [...], Kraków: Florian Ungler, 1534, cz. IV, s. 7a. 
Bartosz Paprocki z kolei widział w nim ucieleśnienie pokory ${ }^{22}$, zaś Biernat z Lublina w swoim Ezopie eksponuje dwoistość tego stworzenia, opisuje je jako przebiegłe i niebezpieczne. Jego niewinny wygląd może zwieść nieświadome zagrożenia myszy. Ludzie, spoglądając na kota, powinni zatem pamiętać, że

Bywać postawa pokorna,

Ale pod nią myśl niewierna.

I drugić się będzie bożył,

By łatwiej swej zdrady pożył ${ }^{23}$.

Bardzo ciekawym utworem jest też tekst Mikołaja Reja znany jako Rozmowa lwa z kotem, w której to kot, choć mniejszy i (jak stwierdza z pogardą okazalszy od niego lew) ma „twarz [...] Ku diabłu barzo podobną [...] ale we łbie płochą sprawę" ${ }^{24}$, okazuje się zwycięzcą dialogu, gdyż jest wolny, w przeciwieństwie do lwa uwięzionego „w klozie” (tj. klatce).

Już tych kilka przykładów wystarczająco dobrze ukazuje niejednoznaczny charakter tego zwierzęcia. Inaczej przedstawiono to w żywocie św. Dominika, w którym kot ma jednoznaczną (negatywną) wymowę: jest straszny i „sprosny”, a więc budzący wstręt, obrzydzenie. Nie przez przypadek ukazuje się on "paniom w kacerstwie uwichłanym”: słowo „kacerz” wywodzi się bowiem od niemieckiego słowa der Ketzer (z greckiego: katharós = czysty), kojarzonego przez podobieństwo z innymi leksemami: die Katze (tj. kot) oraz der Kater (kocur) ${ }^{25}$. Do dziś zresztą świadkowie Jehowy bywają obraźliwie określani jako „kociarze” czy wyznawcy „kociej wiary” przez tych, którzy uznają ich za heretyków. Kacerze, a zwłaszcza ich przywódcy, tak zwani ministrowie, byli

22 B. Paprocki, Panosza [...], Kraków: Maciej Wirzbięta, 1575, s. Z2.

${ }_{23}$ Biernat z Lublina, Żywot Ezopa Fryga [...], Kraków: Stanisław Szarffenberger, 1578, s. P3.

${ }^{24} \mathrm{M}$. Rej, Kot ze lwem rozprawia, Biblioteka Książąt Czartoryskich w Krakowie, rkps 3581 I, s. 392.

${ }^{25}$ D. Sztych, Kot..., s. 25; zob. też Kacerz, hasło w: Słownik wyrazów obcych $P W N$, red. J. Tokarski, Warszawa 1971. 
uznawani za ucieleśnienie Szatana ${ }^{26}$. Żywoty zaś są dziełem szczególnie poświęconym walce $z$ heterodoksją, o czym kaznodzieja wspomina już na wstępie. Kacerzom przypisywano wiele demonicznych cech, a obraz przebiegłego kota, chwytającego bezbronne myszy, przywodził na myśl diabła, chwytającego ludzkie dusze w sidła grzechu ${ }^{27}$. Kacermistrzowie (zwani też, jak wspomniano, ministrami) odznaczali się ponadto mądrością, znali dobrze Pismo Święte (oczywiście wedle katolików przeinaczali je), dlatego też byli szczególnie niebezpieczni. Warto jeszcze dokładniej przyjrzeć się omawianej scenie, mianowicie temu, jak ów piekielny kot się zachowuje. Otóż łasi się, przed dłuższą chwilę ociera się o grzeszne niewiasty, okazuje im swoją sympatię, przywiązanie. I tak jest $\mathrm{w}$ istocie: grzesząc, podobamy się diabłu.

Jeszcze jednym ciekawym przykładem manifestacji złego ducha w postaci zwierzęcej jest sen świątobliwego Nonnusa biskupa, który nawrócił nierządnicę Pelagię. Oto, jak zetknięcie ze Złym relacjonuje sam bohater żywota:

Widziałem u rogu ołtarza czarną jakąś gołębicę, szpetną i sprosną, latała około mnie, czułem smród jej i sprosności wytrwaciem nie mógł, a jednak trwała przy mnie, aż gdy wiernym niechrzczonym wyniść kazano. A po mszy i po skończeniu ofiary gdym z kościoła wychodził, przyleciała po wtóre, sprosna i szpetna około mnie latając. A jam ją wziąwszy, wrzucił w wodę, która była w przysionku kościelnym, w której ona tak wszytkiego plugastwa zbyła, iż piękna jako śnieg wzgórę wzleciała [SkarŻyw 933-934].

${ }^{26}$ W Żywotach Skarga stwierdza wprost, że są to „przesłańcy antychrystowi” [SkarŻyw 57], konstatuje, że: „heretycy towarzystwo z czarty mają” [SkarŻyw 92]. Innowiercy, jak diabeł, boją się znaku krzyża [zob. SkarŻyw 92]. Zob. J. Tazbir, Obraz heretyka i diabła w katolickiej propagandzie wyznaniowej XVI-XVII w., „Kwartalnik Historyczny" 88 (1981), nr 4, s. 944 i nn. Zob też hasła Kacerz i Kacermistrz w Słowniku polszczyzny XVI w. (wersja elektroniczna): Kacerz, http://spxvi.edu.pl/indeks/ haslo/56406\#znaczenie-1 (dostęp: 19.09.2019); Kacermistrz http://spxvi.edu.pl/indeks/haslo/56398\#znaczenie-1 (dostęp: 19.09.2019).

${ }_{27}$ Niemieckie słowo der Ketzer oznacza także rodzaj sieci, którą łowiono raki: metaforycznie więc kacerze łowią w swe sieci dusze nieszczęsnych ludzi, którzy dają im się zwieść. W Żywotach Skarga wspomina o „sieciach” i „siatkach” na dusze wiernych [zob. np. SkarŻyw 74, 341, 459]. 
W wizji tej pojawia się kilka elementów. Z jednej strony należy ją uznać za dręczenie (biskup czuje fizyczny dyskomfort w związku z pojawieniem się gołębicy), z drugiej - jest to odmiana nawiedzenia szatańskiego (scena, jak w żywocie św. Dominika, znów rozgrywa się w świątyni), wreszcie: demon nie przychodzi do Nonnusa wprost, ale nachodzi go (de facto) opętana przez diabła dusza, tu ukazana jako zbrukana i śmierdząca gołębica. Warto odnotować w tym miejscu, że wszystkie zwierzęta, które pojawiają się w związku z osobą czarta bądź też z jego sługami - opętanymi - są ukazane w sposób karykaturalny, zniekształcony. Opisany w wizji św. Dominika kot nie przypominał normalnego kota, miał bowiem cechy, które nie przystają do standardowej charakterystyki tego zwierzęcia (niezwykły wzrost, krwawy język), podobnie gołębica. Co ważne, ptak ten tradycyjnie w ogóle nie jest łączony z demonem, wręcz przeciwnie: najczęściej jego zjawienie się przywodzi na myśl Ducha Świętego, będącego zaprzeczeniem Szatana. W omawianym przypadku gołębica - podobieństwo Trzeciej Osoby Trójcy Świętej, utożsamiana też z duszą ludzką, jako że ciało (w myśl nauki św. Pawła) jawi się jako świątynia Ducha Świętego - zmienia się w Jego przeciwieństwo ${ }^{28}$. Deformacja stworzenia pojawiająca się w opisanych powyżej scenach, ale także w innych żywotach oraz na wymienionych wyżej plastycznych przedstawieniach szatańskich bestii, jest istotna. Diabeł w zetknięciu ze stworzeniem niszczy to, co piękne, boskie, harmonijne, i zmienia postać stworzenia w odrażającą karykaturę. Jego działanie jest więc odwrotne do stwórczej pracy Boga, który wprowadza w naturę piękno i ład.

Kiedy „gołębica sprosna”, to jest Pelagia, zostaje nawrócona, ochrzczona i bierzmowana przez Nonnusa, Szatan nawiedza ją ponownie, a jego przymilne zachowanie przypomina zachowanie piekielnego kota względem kobiet opisanych w żywocie św. Dominika. W akcie obrony święta czyni znak krzyża i chucha na czarta (to

${ }_{28}$ Gołąb, w: Leksykon symboli - Herder, [oprac. oryg. M. Oesterreicher-Mollwo], przeł. J. Prokopiuk, red. L. Robakiewicz, Warszawa 2009; Gołąb, w: M. Lurker, Słownik obrazów i symboli biblijnych, przeł. K. Romaniuk, Poznań 1989. 
ciekawy i nieobecny w dzisiejszym rycie liturgicznym gest egzorcyzmu, związany z przyzywaniem Ducha Świętego w czasie sakramentu chrztu ${ }^{29}$ ): wówczas moc kusiciela zostaje ostatecznie zniweczona.

Opisany wyżej przypadek, kiedy z opętaniem wiąże się sylwetka ptaka, nie jest w Żywotach jedynym. Ptak, tym razem jako realne ucieleśnienie diabła, pojawia się w scenie egzorcyzmu w żywocie św. Gawła. Podobnie jak scena kuszenia św. Antoniego, jest to niezwykle ciekawy fragment, gdyż przekazuje pewną wiedzę na temat tego, jak postrzegano wówczas demona. Zły duch, który w tej historii opętał Frydeburgę, córkę królewską, nie daje się wypędzić ośmiu biskupom. Mało tego, wylicza ich grzechy, które są właśnie powodem ich bezsilności wobec Szatana. W żywocie czart ukazuje się więc jako istota niezwykle inteligentna. To już nie są bezmyślne mary, próbujące przestraszyć egzorcystów, ale godny przeciwnik, którego nie sposób zlekceważyć, bo dysponuje on wiedzą o człowieku, a wręcz zna tajemnice jego duszy, głęboko skrywane przed innymi. Jawi się też jako egzekutor boskich wyroków i Bożego gniewu. Kiedy bowiem biskupi próbują go wygonić, ten nie tylko wylicza ich mnogie grzechy, ale używa wobec nich siły, a nawet próbuje zgładzić jednego z nich mieczem. Czarta cechuje więc nadludzka siła (miota on dziewczyną na wszystkie strony, nie mogą nad nią zapanować jej bliscy ani wezwani na pomoc biskupi) i niespotykana wiedza, umiejętność widzenia rzeczy zakrytych. Ten obraz opętania jest zatem w zasadzie typowy, odpowiada także współczesnym wyobrażeniom na ten temat ${ }^{30}$. W finale wypędzenia diabła dokonuje

${ }^{29}$ Zob. SkarŻyw 278, marginalium (kaznodzieja wymienia tu wszystkie stosowane wówczas elementy składowe chrzcielnego egzorcyzmu): „Chuchanie, krzyżmo abo ś. Olej i zaklinanie czarta przy chrzcie”. Gest ten jest związany z przyzywaniem Ducha Świętego, utożsamiany z boskim tchnieniem życia (por. fragment apokryfu, znajdujący się w Kronice wszystkiego świata M. Bielskiego (Kraków: Mateusz Siebeneicher, 1564, s. 464): „gdy mu lepili [lege: lepiły - dzieci Jezusowi - E.C.-B.] ptaszki z gliny, stawiali [lege: stawiały - E.C.-B.] je podle drogi kędy szedł, a on na ony ptaszki skoro chuchnął, wzlatali wzgórę jako żywi”.

${ }^{30}$ J. Dębiec, Opętanie. Próba psychologicznego ujęcia problemu, Kraków 2000; A. Posacki, Egzorcyzmy, opętanie, demony, Radom 2005; E. Sorensen, Possession and 
pokorny mnich Gaweł (zwany też Gallusem), który już wcześniej daje dowód swej świętości, gdy w lesie poskramia groźnego niedźwiedzia. Kiedy przychodzi do królewny, ta, wyczerpana, akurat odpoczywa, ale spokój tej sceny jest tylko pozorny, bowiem z ust panny unosi się „smród siarczysty i sprosny”, tradycyjnie wiązany z obecnością złego ducha. Kiedy mnich kładzie ręce na głowę dziewczyny i rozpoczyna modlitwę, otwiera ona oczy, ale to nie ona, lecz - co Skarga wyraźnie podkreśla - „czart, patrząc na św. Gallusa”, zaczyna rozmawiać z egzorcyzmującym go mnichem. Co ciekawe, Szatan zachowuje się spokojnie. Jego misja się zakończyła, albowiem działanie diabła miało (w tym przypadku) poświadczyć, że to Gallus jest Bożym wybrańcem, nie zaś żyjący w grzechach biskupi, którzy sprzeniewierzyli się swemu powołaniu. Opętanie Frydeburgi było więc dopustem Bożym: sytuacją, gdy Stwórca zezwala na zło w konkretnym celu (tu: ukaranie purpuratów i wskazanie na prawdziwie świętego, pokornego męża). Ostatecznie Gaweł wygania złego ducha „na przepaść i wieczne potępienie od Pana”, zaś ten opuszcza w końcu ciało dziewczyny pod postacią czarnego ptaka, ulatującego z jej ust.

Podczas egzorcyzmów demon zjawia się też w bardziej przewidywalnej postaci - węża (częściej: wielu wężów), które wychodzą z ciała osoby opętanej. Tak zostaje to przedstawione w żywocie św. Bernata oraz św. Monegundy. Czasami węże pojawiają się także w opowieściach o cudach związanych z uzdrawianiem (choroba była uznawana wówczas za karę Bożą, a więc traktowana jako dopust Boży: kara za grzechy lub próba, można ją było interpretować jako zjawisko o diabelskiej genezie) $)^{31}$. Co interesujące, sposoby uzdrawiania stosowane przez świętych czasami do złudzenia wręcz przypominają szamańskie obrzędy: tak jest właśnie w przypadku Monegundy, która kurując

Exorcism in the New Testament and Early Christianity (Wissenschaftliche Untersuchungen zum Neuen Testament, 2. Reihe, 157), Tübingen 2002.

31 W. Przygoda, Teologia choroby, „Śląskie Studia Historyczno-Teologiczne” 33 (2000), s. 257-266 (zob. zwłaszcza s. 258-264). 
dotkniętą chorobą osobę, posługuje się ziołami i specjalnymi gestami, leczy także śliną (tę wydzielinę stosował także Jezus, co poświadcza ewangelijna scena $\mathrm{z}$ niewidomym od urodzenia). Moc uzdrawiającą mają nie tylko święci, ale także relikwie. Na przykład kapica Piotra z Werony, męczennika, uleczyła dostojnika Gaufryda de Lomello. Skarga nie bez przyczyny wymienia tu nazwisko uleczonego, gdyż zwiększa to wiarygodność opowieści. Szlachcic wyleczył chory żołądek poprzez włożenie na piersi wzmiankowanej kapicy. Jak zaświadcza kaznodzieja, wskutek tego działania: „robaka o dwu głowach kosmatego wracanim wyrzucił i ozdrowiał". Identyczne motywy można spotkać w relacjach podróżników, którzy mieli okazję przyglądać się szamańskim seansom. Schorzenie wychodzi zwykle przez usta człowieka, upostaciowione właśnie jako robak ${ }^{32}$.

Szatański bestiariusz dopełnia jeszcze wizerunek smoka, który pojawia się w Żywotach kilka razy i raz oznacza fantastyczne i groźne zwierzę, a innym razem jest ucieleśnieniem diabła. $W$ obu jednak wariantach smok jest istotą zdecydowanie negatywną, szkodzi człowiekowi i należy go zgładzić, aby przywrócić ład. Szczególny jest też przypadek, kiedy święty, dokonując egzorcyzmu, nakazuje Szatanowi opętać ciało smoka, który następnie zostaje unicestwiony. Draco czasem występuje także jako serpens: w dawnym języku polskim „smok" $i$ „wąż" to wyrazy pokrewne semantycznie, może nawet synonimiczne ${ }^{33}$. Po raz pierwszy pojawia się on oczywiście w Biblii, gdzie

32 A. Szyjewski, Szamanizm, Kraków 2005, tu zwłaszcza rozdziały 2 i 3. Mimo podobieństwa należy jednak uznać odrębność chrześcijańskich i szamańskich sposobów postrzegania i leczenia choroby (wynikającą choćby z odrębności kręgów kulturowych). Analogie mogą mieć źródło w tym, że dawniej (i to nie było uzależnione od kultury) leczono wszystkim, co było dostępne (zioła, minerały, wydzieliny ludzkie i zwierzęce etc.), wierzono w moc słowa (u szamanów było to tzw. kamłanie, w przypadku świętych - modlitwa), stąd podobieństwo obu obrazów uzdrawiania.

${ }_{33}$ Oczywiście mam na myśli polszczyznę szesnastowieczną, a zatem taką, którą posługiwał się Skarga. Wcześniej słowa te różnicowano semantycznie. Wyraz serpens oznaczał węża (w znaczeniu: zwierzę, nie zaś stworzenie fantastyczne), a draco odnosił się raczej do smoka. Już u Mączyńskiego widać jednak, jak stopniowo leksemy te zbliżały się do siebie. Lexicon (s. 95b) odnotowuje, iż draco to „smok 
jego starotestamentowym uosobieniem jest wąż z raju oraz Lewiatan (utożsamiany też czasem $\mathrm{z}$ wielorybem lub bliżej nieokreślonym potworem morskim) oraz w nowotestamentowej Apokalipsie, gdzie jawi się już wyraźnie jako „smok, wąż starodawny”: przeciwnik mającego się narodzić Syna Bożego. W Żywotach święci tak właśnie nazywają czarta, zwłaszcza w starciu z nim, jak czynił to św. Romuald, którego Szatan dręczył przez pięć lat, nie pozwalając mu się porządnie wyspać. Święty, który był doświadczonym pustelnikiem i nie bał się byle czego, wprost łajał Szatana, nie przebierał w słowach, gdy się do niego zwracał: „Sprosniku z nieba zrzucony, co masz tu na puszczy czynić? Psie nieczysty, precz! Precz, stary wężu, na stronę!” [SkarŻyw 571]. Obelga ta przywołuje nie tylko węża, ale również psa. Wcześniej pojawił się on też w zastępie bestii, które dręczyły św. Antoniego. Zwierzę to, podobnie jak wilk, było uznawane za nieczyste, ponadto psy roznosiły wściekliznę, która jako choroba nieuleczalna budziła lęk, zaś jej objawy przypominały opętanie przez diabła. Co jeszcze jest warte podkreślenia $\mathrm{w}$ tej scenie, to fakt, że święty w ogóle wydaje się nieporuszony szatańską obecnością. Cezary Wodziński w swojej pracy Św. Idiota zauważa coś, co pojawia się i u Skargi: święci (szczególnie pustelnicy) często poszukują towarzystwa czartów po to, by z nimi walczyć i w ten sposób dokonywać nie tylko ich „pogromienia”, ale i wyrabiać w sobie cnoty ${ }^{34}$. Taka postawa cechowała nie tylko św. Romualda, ale też na przykład św. Dunstana, który spotykał złego ducha w ciele „męża”, który odmieniał wciąż swoją postać i w ten sposób dał się zdemaskować. Doprowadziło to do sytuacji komicznej:

[...] i obaczy, a z onego męża raz niewiasta, drugi raz dziecię: poznał czarta. I milcząc, rozpalił kleszcze gorąco i wyrwawszy z ognia, uchwycił jemi czarta za nos i ściskał i trzymał, a czart wrzeszczał i wydzierał się [SkarŻyw 508].

albo wąż o czterech nogach". Zob. też hasła Smok, w: Stownik staropolski, t. 8, z. 5: Smętek-Stać, red. S. Urbańczyk et al., Wrocław 1980; Wą̇, w: Stownik staropolski, t. 10, z. 1: W-Wesele, red. S. Urbańczyk et al., Wrocław 1988.

${ }^{34}$ C. Wodziński, Św. Idiota. Projekt antropologii apofatycznej, Gdańsk 2009, s. 73 i nn. (rozdział: Bies jurodiwego). 
Innym razem ten sam mnich widział demona jako straszliwego niedźwiedzia, który go jednak także nie przestraszył:

Raz ukazał mu się na modlitwie czart jako wielki a srogi niedźwiedź, paszczekę nań rozdzierając. A on kij, który nosił, porwał i uderzył go i gonił: bijąc tak długo, aż mu się kij na trzy części spadał. A gdy czart wzniknął, rzekł: przyjdźże drugi raz, najdzie na cię Dunstanus lepszy kij i mięższy, który się nie tak rychło spada. I dostawszy kija mocnego na wierzchu weń wprawił w srebro kość abo ząb świętego Jędrzeja i onym kijem płoszał czarty, gdy mu niepokoje czynili [SkarŻyw 509].

W tych fragmentach Szatan zostaje całkowicie pozbawiony swego autorytetu. Nie jest groźny, ale śmieszny, bardziej przypomina ludowego diabła, którego rola ogranicza się do czynienia złośliwych psot, utrudniających mnichom życie, przeszkadzających w pracy $^{35}$, niż demonicznego władcę ciemności. Takich obrazów jest w żywotach jednak mało, przeważają te ukazujące diabła jako groźnego przeciwnika, przybierającego straszliwą bądź uwodzicielską postać, czasami jednak sposoby kreowania wizerunku diabła łączą się. Tak jest w bardzo sugestywnej wizji św. Małgorzaty, w której znów pojawia się on jako smok w towarzystwie rzeszy pomniejszych demonów o wężowym ciele. Święta

widziała straszliwego smoka, który do niej szedł z trzęsieniem ziemie, wlokąc za sobą niezliczone węże, który paszczekę swą rozdzierając, okrążył panienkę, chcąc ją pożreć. Panna dosyć barzo przestraszona poznała nieprzyjaciela, z którym walkę miała, iż to był diabeł. [...] I gorącą z serca modlitwę puściła w niebo, a krzyżem się świętym żegnając, zawołała o pomoc do Chrystusa. Wnetże się on smok rozpukł i zniknął, i przepadł z wszytkimi wężmi jadowitymi [SkarŻyw 674].

W tym przypadku, mimo że sytuacja wydaje się niebezpieczna, to unicestwienie smoka jest równie kuriozalne, jak opisane wcześniej

35 J. Jakóbiec, Dyabeł w pojęciu ludowem, „Lud” (1899), t. 5, s. 365-367; L.J. Pełka, Polska demonologia ludowa, Warszawa 1987. Por. też wspomniany wyżej rozdział Św. Idioty... C. Wodzińskiego. 
boje pustelników z kusicielem. Pod wpływem egzorcyzmującej mocy modlitwy oraz znaku krzyża - pęka on z hukiem i znika. Bardzo interesująco przedstawia się motyw smoka i Szatana jeszcze w żywocie św. Afry, która była początkowo nierządnicą. Jest to kolejny z żywotów, który skłania do filozoficznej refleksji nad złem, a nawet możliwością zbawienia Szatana. Podczas potężnego rytuału egzorcyzmów, których dokonuje biskup Narcyzus, Szatan występuje znów jako istota inteligentna, a nawet świadoma nędzy swej kondycji, swej ontologicznej pustki. Szatan wydaje się zatem stworzeniem w jakiś sposób tragicznym. Wie, że gra z biskupem o swoje „być albo nie być", i dlatego długo targuje się z nim o duszę Afry:

O święty Narcyzie, co tu czynisz? U sług moich mnie oddanych i na mej służbie zabawionych? Wszak Bóg twój czystych dusz pragnie i ciała czyste i ofiary niezmazane miłuje. To są moje, nie inszego. Gdzie czystość panuje, tam ja nie idę [SkarŻyw 732].

Zły duch nie chce opuścić jej ciała, bo ma świadomość tego, że jest to równoznaczne $\mathrm{z}$ osunięciem się $\mathrm{w}$ niebyt. W pewnym momencie pojedynku z biskupem Szatan zwraca się do niego z osobliwą prośbą, która odwołuje się do żywej w dobie kontrreformacji dysputy nad herezją Orygenesa, dotyczącą możliwości zbawienia Szatana ${ }^{36}$ :

Rzekł szatan: cudzego nic brać nie masz, jeśliś święty. A biskup mu łajał, mówiąc: Złodzieju! Pokradłeś to, nie twoje jest! Stworzenie to jest Boże, które ja Stworzycielowi wracam! Rzekł czart: Jam też Jego stworzenie, mnie Mu też wróć. Odpowie Biskup: by za was Chrystus ucierpiał i bych to uczynił, ale za ludzie ucierpiał, nie za was. A czart prosił, aby mu tylko jedną duszę zostawił. [...] Rzekł biskup: Zostawię ci duszę jednę, która je, pije, trawi, śpi, czuje. Ale obiecaj mi wnet ją zabić. [...] i rzekł Narcyzus: idźże do

${ }^{36} \mathrm{O}$ kontrowersjach w poglądach Orygenesa na temat zbawienia Szatana zob. J. Pochwat, Złe duchy - diabeł $i$ demony na podstawie Homilii o Księdze Psalmów Orygenesa-Hieronima, „Vox Patrum” 33 (2013), t. 59, s. 129 i nn.; M. Szram, Kościół jako rzeczywistość wieczna $w$ doktrynie Orygenesa, „Verbum Vitae” 6 (2004), s. 221; B. Czyżewski, Orygenesowe elementy egzegezy i nauki w komentarzu Do Księgi Jonasza św. Hieronima, „Biblica et Patristica Thoruniensia” 2 (2009), s. 148 i nn. 
źródła, które jest w górach [...] wody onej nikt pić nie może [...] przeto, iż tam smok mieszka, który jadem swym wodę zaraża. Zabijże go a duszę jego weźmi [SkarŻyw 733].

Szatan, zaklęty znakiem krzyża i złożoną świętemu obietnicą, jest zmuszony wykonać polecenie. Wchodzi w ciało smoka, który natychmiast pada martwy. To jednak sprawia, że istnienie demona zostaje zakończone, bowiem prawdziwą żertwą dla niego są ciała i dusze ludzi, a nie zwierząt.

Jeszcze jeden obraz smoka pojawia się w żywotach i jest to już konwencjonalny motyw świętego pokonującego bestię. Pojawia się on w żywocie św. Teodora:

[Smok - E.C.-B.] był tak wielki, iż gdy się ruszył, ziemia pod nim drżała, a kamienie się kruszyło. [...] którego wyzywać począł św. Teodor: w imię Jezusa Chrystusa, Pana naszego, wynidź sam! Gdy się ruszać smok począł, a ziemia drżała, ś. Teodor, przeżegnawszy się, na koń wsiędzie i gdy na oko smoka ujrzy, konia zewrze, a koń na smoka wskoczył wszytkimi nogami i przycisnął do ziemie. A tymczasem głowę mu ściął Teodor [SkarŻyw 187].

Tutaj walka z potworem ma wymiar symboliczny i obrazuje wyzwolenie spod władzy zła, pokonanie go (smok, prezentowany w tej historii jako stworzenie chtoniczne, oznacza ciemne moce i siły natury zagrażające człowiekowi). Sens zaś literalny żywota oznacza po prostu niezwykłą odwagę, zdolność dokonywania czynów bohaterskich nie dla próżnej sławy, ale dla dobra innych (gad nękał mieszkańców miasteczka, porywając ludzi i trzodę).

Przedstawione w niniejszym szkicu wizerunki zoomorficznych inkarnacji Szatana stanowią jeden ze sposobów istnienia świata zwierzęcego w tekście Żywotów świętych. Motywy te nie są samodzielnymi całościami, lecz elementami tak zwanych mirakulów, które są słabo zbadane i przez długi czas były przez badaczy deprecjonowane, jako przejaw zabobonu i naiwności ${ }^{37}$. Przedstawiona analiza nie stanowi

37 Zob. na przykład J. Tazbir, Piotr Skarga. Szermierz kontrreformacji, Warszawa, 1978, s. 104-107, 111; H. Barycz, Z dziejów jednej książki, w: idem, Z epoki renesansu, reformacji i baroku. Prądy, idee, ludzie, książki, Warszawa 1971, s. 656-657. Nawet 
wyczerpującego opisu, gdyż rekonstruuje tylko jeden z wymiarów tego, jak zwierzęta są ukazywane w dziele jezuity. Zostało wszakże zasygnalizowane, że ich rola w zasadzie nigdy nie jest ograniczona do jednego tylko aspektu: bycia ucieleśnieniem zła bądź dobra. W opowieściach o zmaganiach świętych ze złym duchem stworzenia takie jak wąż (smok), niedźwiedź, pies, kot, czarny ptak czy robak są uosobieniami sił niszczących, ale w innych historiach - na przykład o pustelnikach czy męczennikach - odgrywają one rolę jak najbardziej pozytywną. Dopiero przeanalizowanie również i tych opowieści dopełni obrazu całości i pozwoli kompletnie określić znaczenie wątków animalnych w Żywotach. I chociaż nie są one głównym ich motywem, to jednak powinny być analizowane, gdyż dopełniają interpretacji monumentalnego dzieła, a czasem odsłaniają treści, których badając inne, bardziej nawet znaczące części utworu, odsłonić nie sposób.

\section{Bibliografia}

\section{Źródła}

Bielski M., Kronika wszystkiego świata, Kraków: Mateusz Siebeneicher, 1564.

Biernat z Lublina, Żywot Ezopa Fryga [...], Kraków: Stanisław Szarffenberger, 1578. Bułhakow M., Mistrz i Małgorzata, przeł. L.A. Przebina, G. Przebina, I. Przebina, Kraków 2016.

Eire. Wiersze irlandzkie: VI-XIX wiek, wybór, przeł. i oprac. E. Bryll, M. Goraj-Bryll, [zebrał i oprac. R. Bąk], Warszawa 2004.

wcześniejsze ustalenia Tadeusza Grabowskiego (zob. T. Grabowski, Piotr Skarga na tle katolickiej literatury religijnej w Polsce, Kraków 1913, s. 308) czy późniejsze prace Janusza Pelca (zob. J. Pelc, Kontrreformacja, sarmatyzm a rozwój literatury polskiej, w: Wiek XVII - kontrreformacja - barok. Prace z historii kultury, red. idem, Wrocław, 1970, s. 99) nie skłaniały wyżej wymienionych badaczy do zmiany stanowiska w tej kwestii. Tazbir dostrzegał wprawdzie w Żywotach pewną nowoczesność, ale Barycz upatrywał ich sukcesu jedynie w „dobrze utrafionym momencie dziejowym” oraz (co gorsza) w „odczuciu ciasnych potrzeb społeczeństwa” (H. Barycz, $Z$ dziejów jednej ksiązki, s. 656-657). 
Falimirz S., O ziołach i o mocy ich [...], Kraków: Florian Ungler, 1534.

Mączyńki J., Lexicon latino-polonicum ex optimis latinae linguae scriptoribus concinnatum, Królewiec: Jan Daubman, 1564.

Paprocki B., Panosza [...], Kraków: Maciej Wirzbięta, 1575.

Rej M., Kot ze lwem rozprawia, Biblioteka Książąt Czartoryskich w Krakowie, rkps $3581 \mathrm{I}$.

Skarga P., Żywoty świętych, Wilno: Drukarnia Radziwiłłowska, 1579.

\section{Opracowania}

Amorth G., Wyznania egzorcysty, przeł. W. Zasiura, Częstochowa 2006.

Barycz H., Z dziejów jednej książki, w: H. Barycz, Z epoki renesansu, reformacji i baroku. Prądy, idee, ludzie, książki, Warszawa 1971.

Ceccherelli A., Od Suriusa do Skargi. Studium porównawcze o „Żywotach świętych”, przeł. M. Niewójt, Izabelin 2003.

Cholwińska H., Zagadnienie genezy zła w myśli św. Augustyna, „Studia Theologica Varsaviensia” 37 (1999), nr 1.

Cooper J.C., Zwierzęta symboliczne i mityczne, przeł. A. Kozłowska-Ryś, L. Ryś, Poznań 1998.

Cybulska-Bohuszewicz E., „Żywoty świętych” Piotra Skargi - biografie transgresyjne. Prolegomena do przyszłych badań, „Autobiografia. Literatura. Kultura. Media” (2018), nr 2.

Czyżewski B., Orygenesowe elementy egzegezy i nauki w komentarzu Do Księgi Jonasza św. Hieronima, „Biblica et Patristica Thoruniensia” 2 (2009).

Dębiec J., Opętanie. Próba psychologicznego ujęcia problemu, Kraków 2000.

Grabowski T., Piotr Skarga na tle katolickiej literatury religijnej w Polsce, Kraków 1913. Jakóbiec J., Dyabeł w pojęciu ludowem, „Lud” (1899), t. 5.

Kapuścińska A., „Żywoty świętych” Piotra Skargi. Hagiografia - parenetyka - duchowość, Szczecin 2008.

Kielak O., Zwierzęta domowe a postaci demoniczne w języku i kulturze, „Kultura i Historia” (2017), nr 32.

Kiszkowiak K., W kręgu topiki hagiograficznej. „Żywoty świętych” Piotra Skargi, Kraków 2008.

Leksykon symboli - Herder, [oprac. oryg. M. Oesterreicher-Mollwo], przeł. J. Prokopiuk, red. L. Robakiewicz, Warszawa 2009.

Lurker M., Słownik obrazów i symboli biblijnych, przeł. K. Romaniuk, Poznań 1989.

Miniatura i mikrologia literacka, t. 1-3, red. A. Nawarecki, Katowice 2000-2003.

Nawarecki A., O śląskiej szkole mikrologii (1999-2005). Garść wspomnień, „Forum Poetyki” 2017, http://fp.amu.edu.pl/o-slaskiej-szkole-mikrologii-1999-2005-garsc-wspomnien/ (dostęp: 19.09.2019).

Nawarecki A., wstęp do: Miniatura i mikrologia literacka, t. 2, red. A. Nawarecki, Katowice 2000. 
Nizwandowski J., Bóg a zło. Na marginesie „O naturze dobra”, „Znak” 95 (1962).

Nowicka-Jeżowa A., Pokolenia trydenckie między tradycją a wyzwaniami przyszłości, w: Formowanie kultury katolickiej w dobie potrydenckiej. Powszechność i narodowość polskiego katolicyzmu, red. J. Dąbkowska-Kujko (Kultura Pierwszej Rzeczypospolitej w Dialogu z Europą. Hermeneutyka Wartości, t. 6), Warszawa 2016.

Pelc J., Kontrreformacja, sarmatyzm a rozwój literatury polskiej, w: Wiek XVII kontrreformacja - barok. Prace z historii kultury, red. J. Pelc, Wrocław 1970.

Pełka L.J., Polska demonologia ludowa, Warszawa 1987.

Pochwat J., Złe duchy - diabet i demony na podstawie Homilii o Księdze Psalmów Orygenesa-Hieronima, „Vox Patrum” 33 (2013), t. 59.

Posacki A., Egzorcyzmy, opętanie, demony, Radom 2005.

Przybylski R., Pustelnicy i demony, Kraków 1994.

Przygoda W., Teologia choroby, „Śląskie Studia Historyczno-Teologiczne” 33 (2000).

Rutkowski P., Kot czarownicy. Demon osobisty w Anglii wczesnonowożytnej, Kraków 2012.

Skala mikro w badaniach literackich, red. A. Nawarecki, M. Bogdanowska, Katowice 2005.

Słownik polszczyzny XVI w. (wersja elektroniczna): Kacerz, http://spxvi.edu.pl/indeks/haslo/56406\#znaczenie-1 (dostęp: 19.09.2019); Kacermistrz, http://spxvi. edu.pl/indeks/haslo/56398\#znaczenie-1 (dostęp: 19.09.2019).

Słownik staropolski, t. 8, z. 5: Smętek-Stać, red. S. Urbańczyk et al., Wrocław 1980. Słownik staropolski, t. 10, z. 1: W-Wesele, red. S. Urbańczyk et al., Wrocław 1988. Słownik wyrazów obcych PWN, red. J. Tokarski, Warszawa 1971.

Sorensen E., Possession and Exorcism in the New Testament and Early Christianity (Wissenschaftliche Untersuchungen zum Neuen Testament, 2. Reihe, 157), Tübingen 2002.

Szram M., Kościół jako rzeczywistość wieczna $w$ doktrynie Orygenesa, „Verbum Vitae" 6 (2004).

Sztych D., Kot - dobrotliwe bóstwo, czy pomiot szatana?, „Przegląd Hodowlany” (2011), nr 11.

Szyjewski A., Szamanizm, Kraków 2005.

Tazbir J., Obraz heretyka i diabła w katolickiej propagandzie wyznaniowej XVIXVII w., „Kwartalnik Historyczny” 88 (1981), nr 4.

Tazbir J., Piotr Skarga. Szermierz kontrreformacji, Warszawa 1978.

Wodziński C., Św. Idiota. Projekt antropologii apofatycznej, Gdańsk 2009. 